\title{
Growth performance, carcass indices and blood profile of broiler chickens fed tiger nut residue
}

\author{
Essien, C. A. \\ Department of Animal Science, Faculty of Agriculture, Akwa Ibom State University, Nigeria. \\ Email: comfortabelessien@gmail.com
}

Copyright (C 2021 Essien. This article remains permanently open access under the terms of the Creative Commons Attribution License 4.0, which permits unrestricted use, distribution, and reproduction in any medium, provided the original work is properly cited.

Received 15th February, 2021; Accepted 5th March, 2021

\begin{abstract}
A total of two-hundred-and-forty day old broiler chicks were used to study the response of broiler birds to diets containing graded levels of tiger nut residue (TNR) as a replacement for maize. The diets consisted of $0,10,20$ and $30 \%$ of TNR as a replacement for maize as $\mathrm{T}^{1}$ (control), $\mathrm{T}_{2}, \mathrm{~T}_{3}$ and $\mathrm{T}_{4}$ respectively. The birds were allotted to four dietary treatments of 4 replicates each containing 60 and 15 birds respectively in a completely randomized design. The data obtained from the experiment were subjected to one - way analysis of variance. The results showed that average weight gain (AWG) and final weight gain (FWG) were high for birds fed 10\% TNR and increased numerically than the 0, 20 and $30 \%$ groups at the starter phase. In the finisher phase the average weight gain (AWG) and final weight gain (FWG) followed the same trend. Feed intake was not significantly affected by the diet at the starter and finisher phases. In the starter phase the $T_{1}$ (control) recorded the best and the lowest feed conversion ratio but in the finisher phase, the best feed conversion ratio was observed in $T_{2}$. The TNR inclusion had no significant $(p>0.05)$ effect on live weight, dressed weight, dressing percentage, cut-parts and organs of the birds. The haematological parameters were not significantly $(p>0.05)$ affected by the diets. All the biochemical parameters determined; serum protein, albumin, globulin, urea, creatinine, ALT, AST, cholesterol and triglyceride were not significantly $(p>0.05)$ affected by the treatment diet. It was concluded that tiger nut residue (TNR) as a replacement for maize at a $30 \%$ level of inclusion did not cause any deleterious effects on the performance, carcass and blood profiles of broilers.
\end{abstract}

Keywords: Blood profile, broiler chicken, carcass, performance, tiger nut residue.

\section{INTRODUCTION}

The quest to increase the protein intake of the everincreasing Nigeria population has long been emphasized thus, calls for the exploitation of every aspect of livestock production especially short generation species like poultry. Poultry meat and eggs offer considerable potential for meeting human needs for dietary animal protein supply (Folorunsho and Onibi, 2005).

Poultry provides the quickest source of meat and its production involves the least hazardous and arduous process compared to other livestock enterprises (Ojewola et al., 2006). Despite the existing enormous and great potentials of poultry, its production is disproportionately lower due to the high cost of compounded feeds which is derived largely from the exorbitant prices of feed ingredients, increasing competition demand for them and scarcity of the conventional ingredients (Ojewola et al.,
2006). This situation has resulted in increased interest in the utilization of unconventional feeding stuff as an alternative for the expensive conventional ones.

In recent times, the effort has been directed towards the utilization of by-products or wastes in animal feeds. The use of agro-by-product as feedstuffs is another way of creating edible protein from waste material which is often disposed of uneconomically. As reported by Aregheore (1998), Nigeria produced large quantities of agricultural and agro-industrial by-products that could serve as an alternative to conventional feed sources and ingredients many of which have proven valuable in enhancing the performance of livestock. Among the many agro-byproducts are maize offal, cassava peels, brewers grains, maize cobs, yam peel, plantain peels, banana peels, rice husk, rice offal etc. However, their availability in terms of 
quantity and quality, coupled with high fiber content is of major concern.

An agricultural waste that seems to have potentials as a source of dietary energy for poultry in Nigeria is tiger nuts residue. Tiger nut residue is produced after the extraction of milk from tiger nut by beverage industries and is discarded as wastes. Information on the value of tiger nut residue as animal feed is limited. However, Samson and Safiya (2013) reported that tiger nut residue is high in carbohydrate, crude fiber, crude lipid (43.0, 18.4 and $24.4 \%$ ) respectively. The authors further reported that tiger nuts residue is rich in iron and vitamins $\left(B_{1}\right.$ and $\left.B_{2}\right)$, and also contain some anti-nutritional substances such as saponins, oxalate and phytate. Sun drying could help to reduce these anti-nutritional substances. Sun drying has been reported to reduce the cyanide content in cassava peels to a safer level (Okike et al., 2015).

Poor nutrition can significantly affect the efficiency of bird's immune system and its growth. Blood is considered as an important material for the evaluation of health status in animals (Arslam et al., 2001). Blood evaluation is commonly used to help diagnose illness in animals (Vetstreet, 2011). It acts as a pathological reflector of the status of exposed animals to a toxicant and other conditions (Olafehehan et al., 2010). Numerous authors have described the use of hematological parameters as a medium of assessing the differences in animals exposed to varying diet composition and the resultant health implications (Annongu and Olawuyi, 2005).

Generally, both the hematological and biochemical components of the blood are influenced by the quantity and quality of feed and also the level of anti-nutritional factors present in the feed (Akinmutimi, 2004). With the high energy content in tiger nut residue reported by Sampson and Safiya (2013), this warrants its trial and utilization in feed formulation. Thus, this study was designed to evaluate the effect of tiger nut residue on the performance, carcass, organs, and blood profiles of finishing broiler chickens.

\section{MATERIALS AND METHODS}

\section{Study site}

This study was conducted at the Poultry Unit of the Teaching and Research Farm, Akwa lbom State University, Obio Akpa Campus, Oruk Anam Local Government Area, Akwa Ibom State, Nigeria. Obio-Akpa is located between latitudes $5^{\circ} 17^{1} \mathrm{~N}$ and $5^{\circ} 27^{1} \mathrm{~N}$ and between longitudes $7^{\circ} 27^{1} \mathrm{~N}$ and $7^{\circ} 58^{1} \mathrm{E}$ with an annual rainfall ranging from 3500 to $5000 \mathrm{~mm}$ and average monthly temperature of $250^{\circ} \mathrm{C}$, and relative humidity between 60 to $90 \%$ (Wikipedia, 2016).

\section{Experimental material and diet}

The tiger nut residue was obtained from tiger nut milk processors at Abak in Abak Local Government Area of Akwa Ibom State. The residue was sun dried for 3 to 5 days to remove moisture so as to prevent microbial build up. Four experimental diets were formulated with tiger nut residue replacing dietary maize at $0,10,20$, and $30 \%$ as $T_{1}, T_{2}, T_{3}$ and $T_{4}$ respectively for both starter and finisher phase (Tables 1 and 2). The diets were formulated to meet the requirement of the National Research Council (1994) for broilers.

\section{Experimental birds and management}

The pens $(2 \mathrm{~m} \times 2 \mathrm{~m})$ were cleaned and disinfected before the arrival of the chicks. A total of two-hundred-and-fortyday old broiler chicks of Marshal Breed were used for the study. The chicks on arrival were placed on the experimental diets. The chicks were allocated to four experimental treatments, replicated four times with 15 birds each in a completely randomized design (CRD). The birds were raised in a deep litter system, using wood shavings as litter material in an open-sided poultry house. Feed and water were supplied ad-libitum throughout the study period. All recommended vaccines were administered as and when due.

Similarly, necessary sanitary measures to guarantee the bio safety of the experimental pens, drinkers and feeders adhered to. At the end of the starter phase which lasted 0 to 4 weeks, birds were weighed and reshuffled to have 9 groups of birds with similar body weight to start the finishing phase and each group was assigned finisher diets. The experiment lasted 56 days.

\section{Data collection}

The live body weights of the birds were obtained weekly. The weight gain was calculated by subtracting the initial weight from the final weight using a $20 \mathrm{~kg}$ capacity weighing balance (Hana spring-platform scale). Feed intake of the birds was calculated by subtracting the quantity of the leftover feed from the quantity of feed fed the previous day. This was later divided by the number of birds in the replicate to give the average feed intake per bird. The feed conversion ratio was calculated by dividing the daily feed intake by daily weight gain. Protein intake was calculated by multiplying the percent of crude protein $(\mathrm{CP})$ in the feed by daily feed intake.

\section{Carcass characteristics and organ weight evaluation}

At the end of the experiment, 3 birds were randomly selected from each replicate, fasted overnight of feed, weighed and slaughtered by severing the jugular vein and allowed to bleed thoroughly. Before de-feathering, the carcass was scalded in hot water of about $70-75^{\circ} \mathrm{Cfor}$ about a minute and the feathers plucked manually. The 
Table 1. Gross composition of experimental diets.

\begin{tabular}{|c|c|c|c|c|c|c|c|c|}
\hline \multirow{2}{*}{ Ingredients } & \multicolumn{4}{|c|}{ Starter } & \multicolumn{4}{|c|}{ Finisher } \\
\hline & $T_{1}$ & $\mathbf{T}_{2}$ & $\mathrm{~T}_{3}$ & $\mathbf{T}_{4}$ & $\mathrm{~T}_{1}$ & $\mathrm{~T}_{2}$ & $\mathrm{~T}_{3}$ & $\mathbf{T}_{4}$ \\
\hline Maize & 50.00 & 40.00 & 30.00 & 20.00 & 55.00 & 45.00 & 35.00 & 25.00 \\
\hline Soya bean meal & 31.00 & 31.00 & 31.00 & 31.00 & 30.00 & 30.00 & 30.00 & 30.00 \\
\hline TNR & 0.00 & 10.00 & 20.00 & 30.00 & 0.00 & 10.00 & 20.00 & 30.00 \\
\hline Fish meal & 4.00 & 4.00 & 4.00 & 4.00 & 3.00 & 3.00 & 3.00 & 3.00 \\
\hline Palm kernel cake & 10.00 & 10.00 & 10.00 & 10.00 & 7.00 & 7.00 & 7.00 & 7.00 \\
\hline Salt & 0.25 & 0.25 & 0.25 & 0.25 & 0.25 & 0.25 & 0.25 & 0.25 \\
\hline Bone meal & 4.00 & 4.00 & 4.00 & 4.00 & 4.00 & 4.00 & 4.00 & 4.00 \\
\hline Premix & 0.25 & 0.25 & 0.25 & 0.25 & 0.25 & 0.25 & 0.25 & 0.25 \\
\hline Lysine & 0.25 & 0.25 & 0.25 & 0.25 & 0.25 & 0.25 & 0.25 & 0.25 \\
\hline Methionine & 0.25 & 0.25 & 0.25 & 0.25 & 0.25 & 0.25 & 0.25 & 0.25 \\
\hline Total & 100 & 100 & 100 & 100 & 100 & 100 & 100 & 100 \\
\hline \multicolumn{9}{|c|}{ Calculated chemical composition } \\
\hline Crude Protein \% & 24.21 & 23.61 & 23.01 & 22.41 & 22.64 & 22.04 & 21.44 & 20.84 \\
\hline Ether extract \% & 4.089 & 4.489 & 4.89 & 5.29 & 3.97 & 4.37 & 4.77 & 5.17 \\
\hline Crude Extract \% & 4.517 & 5.15 & 5.78 & 6.14 & 4.24 & 4.87 & 5.50 & 6.13 \\
\hline Ash & 3.67 & 4.04 & 4.41 & 4.78 & 3.36 & 3.73 & 4.10 & 4.47 \\
\hline $\mathrm{ME}(\mathrm{Kcal} / \mathrm{kg}$ & 2952 & 2922 & 2892 & 28628 & 3033 & 3003 & 2973 & 2948 \\
\hline
\end{tabular}

Premix supplied per kg: Vitamin A 10,000i.u; vitamin $\mathrm{D}_{3}$ 12,000i.u; vitamin E20i.u; vitamin $\mathrm{k} 2.5 \mathrm{mg}$, Thiamine 2.0mg, riboflavin 3.0mg, pyridoxine $4.0 \mathrm{mg}$, Niacin $20 \mathrm{mg}$, Cobalamine $0.05 \mathrm{mg}$, Pantothenic acid $5.0 \mathrm{mg}$, folic acid $0.5 \mathrm{mg}$, biotin $0.08 \mathrm{mg}$, choline chloride $0.2 \mathrm{mg}$, manganese $0.0006 \mathrm{~g}$, zinc $0.03 \mathrm{~g}$, copper $0.006 \mathrm{~g}$, iodine $0.0014 \mathrm{~g}$, selenium $0.24 \mathrm{~g}$, cobalt $25 \mathrm{~g}$, antioxidant $0.125 \mathrm{~g}$, TNR - tiger nut residue.

Table 2. Proximate composition and anti-nutritional factors of tiger nut residue.

\begin{tabular}{lcc}
\hline Components \% (DM) & Values & $\mathbf{\pm S D}$ \\
\hline Moisture & 11.8 & 0.78 \\
Ash & 0.5 & 0.07 \\
Crude protein & 3.0 & 0.17 \\
Crude fiber & 17.21 & 0.78 \\
Crude lipid & 22.51 & 0.07 \\
Nitrogen free extracts & 44.98 & 0.41 \\
Anti-nutrients (mg/100g) & & \\
Tannin & 1.50 & 0.37 \\
Cyanogenic glycoside & 2.11 & 0.01 \\
Alkaloids & 1.73 & 0.13 \\
Oxalate & 2.28 & 0.18 \\
Phytate & 1.13 & 0.01 \\
Saponin & 3.41 & 0.04 \\
Flavonoids & 3.11 & 0.38 \\
\hline
\end{tabular}

Values are means of triplicate determinations; \pm SD - standard deviation.

carcasses were eviscerated and weighed to determine the carcass yield. The weights of the carcass cut parts; breast, thigh, drumstick, back, shank, neck and wing were recorded individually and expressed as a percentage of dressed weight of the broilers while the weight of the organs (gizzard, liver, heart and kidney) and abdominal fat were recorded and expressed as a percentage of live weight.

\section{Blood collection and analysis}

At the end of the experiment, $10 \mathrm{ml}$ of blood samples were drawn from three birds each per replicate making it a total of forty-eight birds through the jugular vein. $5 \mathrm{ml}$ of the blood collected for hematological analysis were transferred into a universal bottle containing ethylene diamine tetra-acetic acid (EDTA) and mixed thoroughly to prevent the blood from clotting. Haemoglobin concentration $(\mathrm{Hb})$ was determined using the Sahl method and the value recorded in $\mathrm{g} / 100 \mathrm{~ms}$ (WHO, 1980). Red blood cells (RBC) and white blood cells (WBC) were determined using the improved Neubauer haemocytometer as described by Dacie and Lewis (1991). Packed cell volume (PCV) was determined by the microhaematocrit method, while means corpuscular volume (MCV), mean corpuscular haemoglobin $(\mathrm{MCH})$ and mean corpuscular haemoglobin concentration $(\mathrm{MCHC})$ were calculated as shown below.

$$
\begin{aligned}
& \operatorname{MCV}(\%)=\frac{\operatorname{PCV} \times 100}{\operatorname{RBC}} \\
& \operatorname{MCH}(\%)=\frac{\operatorname{HB} \times 100}{\operatorname{RBC}}
\end{aligned}
$$


$\operatorname{MCHC}(\%)=\frac{\mathrm{HB} \times 100}{\mathrm{PCV}}$

Another $5 \mathrm{ml}$ of the blood samples were transferred into anticoagulant-free bottles and were used to determined blood biochemical components such as total protein, albumin, urea, creatinine, cholesterol triglyceride, aspartate aminotransferase, and alanine amino transaminase.

\section{Statistical analysis}

Data collected from the various parameters measured were subjected to one way analysis of variance using the SPSS software (2004) where analysis of variance indicated significant treatment effects; means were compared using Duncan's New Multiple Range Test (DNMRT) (SPSS, 2004).

\section{Chemical analysis}

Test ingredients were dried at $60^{\circ} \mathrm{C}$ for 24 hours before analysis. Dry matter (DM), ash, crude protein $(\mathrm{N} \times 6.25)$, ether extract (EE) and crude fiber (CF) were determined according to AOAC (1990) methods. Tannin was determined according to Follin Denis methods (AOAC, 1990); phytate saponin, oxalate, cyanogenic glycosides and alkaloids as described by lyayi, (2008). Average values were taken after four times of analysis.

\section{RESULTS AND DISCUSSIONS}

The result of the proximate composition of tiger nut residue (Table 2) showed that it contains a high level of ether extract and nitrogen-free extracts respectively which could make it a potential energy feedstuff and can partially replace or completely replace conventional energy feedstuffs. The values for crude fiber, crude protein and ash were $17.21,3.0$, and $0.5 \%$ respectively.

Table 3 showed the performance of the broilers at the starter and finisher phases. At the starter phase, there was no significant $(p>0.05)$ difference in the final body weight (FBW) and the average weight gain (AWG) of chicks across treatments. The non-significance $(p>0.05)$ differences that exist across the treatments on average weight gain (AWG) and final weight gain (FWG) of the chicks in the starter phase may be attributed to the low level of anti-nutritional factors presentation in tiger nut residue. The presence of anti-nutritional factors has been shown to reduce growth rate of broiler due to reduced protein and specific amino acid utilization (Douglas et al., 1992; Elkin et al., 2005; Fanimo et al., 2007). At the starter phase, the feed intakes of the chicks were not significantly $(p>0.05)$ affected by the diet. The feed conversion ratio followed the same trend.
At the finisher phase, there was no significant $(p>0.05)$ difference in average weight gain and final weight gain of the broilers across treatments. This result is similar to the report of Archibong et al. (2018), where broiler birds fed tiger nut based diet up to $75 \%$ level did not indicate significant differences ( $p>0.05$ ) in AWG and FWG weights. Ochetim (1993) reported a non-significant weight values when broilers were fed corn cob meal.

At the finisher phase, the feed intake of the broilers was not significantly $(p>0.05)$ affected by the diet. The broilers in $T_{1}$ recorded the lowest values for feed intake while $T_{4}$ recorded the highest but non-significant $(p>0.05)$ feed intake value. The result agreed with the report of Fanimo et al. (2007) that high fiber diet increases feed intake to allow birds meet their requirement for some dietary component other than energy. The result is similar to the findings of Van Krimpen et al. (2006), who reported that higher feed consumption rate could be attributed to an attempt by monogastric animals to increase their feed intake when fed diets containing high levels of insoluble non-starch polysaccharides. However, the non-significant effects in feed intake of the broilers at the final phase could be attributed to the fact that matured birds can tolerate a high level of fiber than young birds (Nsa, 2007). The feed conversion ratio of the birds in the finisher phase was not significantly $(p>0.05)$ influenced by the diets. This result indicated that the birds were able to utilize the nutrient in the feed.

The result of the carcass/cut parts yield and internal organs of the broiler chickens are shown in Table 4. Live weight, dressed weights and dressing percentages of the birds were not statistically influenced by the diet $(p>0.05)$. The values obtained for live weight, dressed weight, and dressing percentages of the birds were statistically $(p>0.05)$ similar across treatments. This result is in line with Archibong et al. (2018) report, where the dressing percentage of broilers fed varying dietary levels of tiger nut-based diets had no significant impacts on broilers. The values obtained in this study for dressing percentage are higher than the values obtained by Ravindran and Savakanessan (1996), as ideal dressing percentages for well finished broilers chickens. Therefore, the results obtained in this study for live and dressed weights of finishing broilers fed tiger nut residue indicated a high performance of the birds which shows that the birds were able to utilize nutrients in the feed.

The mean weights of cut parts as percentage of live weight were not significantly affected by treatment diets. The values for breast, wing, thigh, drumstick, neck, shank and back were statistically $(p>0.05)$ similar across treatment. The result obtained in this study for cut-parts is in consonance with the report of Archibong et al. (2018), where weights of cut parts of finisher broiler fed tiger nutbased diet were not significantly affected $(p>0.05)$ by the treatment diets. The non-significance difference observed in cut-parts weights indicated that diets provided adequately all the needed nutrients for broiler chickens.

The internal organs: liver, kidney and gizzard were not 
Table 3. Effects of replacement of maize with tiger nut residue on the performance of starter and finishing broiler chicks.

\begin{tabular}{lccccc}
\hline \multirow{2}{*}{ Performance Induces } & \multicolumn{5}{c}{ Replacement levels of tiger nut residue starter phase } \\
\cline { 2 - 6 } & $\mathbf{0} \%$ & $\mathbf{1 0 \%}$ & $\mathbf{2 0} \%$ & $\mathbf{3 0} \%$ & $\mathbf{S E M}$ \\
\hline Average Initial body weight $(\mathrm{g})$ & 320.02 & 319.10 & 317.21 & 320.01 & 0.01 \\
Average final body weight $(\mathrm{g})$ & 1105.05 & 1110.01 & 1098.91 & 1087.01 & 0.03 \\
Average body weight gain $(\mathrm{g})$ & 784.85 & 790.91 & 781.70 & 767.00 & 0.10 \\
Average daily weight gain $(\mathrm{g})$ & 28.03 & 28.25 & 27.92 & 27.39 & 0.21 \\
Average feed intake $(\mathrm{g})$ & 58.01 & 60.01 & 63.05 & 64.08 & 0.41 \\
Feed conversion ratio (g feed/g gain) & 2.07 & 2.12 & 2.26 & 2.34 & 0.13 \\
Mortality & 0.00 & 0.00 & 0.00 & 0.00 & 0.00 \\
& & & & & \\
Finisher phase & & & & & \\
Average Initial body weight (g) & 1114.00 & 1116.02 & 1118.31 & 1112.01 & 0.05 \\
Average final body weight (g) & 2545.46 & 2643.34 & 2543.54 & 2498.59 & 0.51 \\
Average body weight gain (g) & 1431.40 & 1527.32 & 1425.23 & 1386.58 & 0.12 \\
Average daily weight gain (g) & 51.12 & 54.55 & 50.90 & 49.52 & 0.31 \\
Average feed intake $(\mathrm{g})$ & 127.02 & 130.01 & 131.03 & 132.50 & 0.03 \\
Feed conversion ratio $(\mathrm{g}$ feed/g gain) & 2.48 & 2.38 & 2.59 & 2.68 & 0.01 \\
Mortality & 0.00 & 0.00 & 0.00 & 0.00 & 0.00 \\
\hline
\end{tabular}

Table 4. The Carcass yield and organ of broiler chicken feed experimental diet.

\begin{tabular}{lccccc}
\hline Parameters & $\mathbf{T}_{\mathbf{1}}$ & $\mathbf{T}_{\mathbf{2}}$ & $\mathbf{T}_{\mathbf{3}}$ & $\mathbf{T}_{\mathbf{4}}$ & $\mathbf{S E M}$ \\
\hline Live weight $(\mathrm{kg})$ & 2.39 & 2.41 & 2.41 & 2.38 & 0.21 \\
Dressed weight $(\mathrm{kg})$ & 1.91 & 1.93 & 1.88 & 1.86 & 0.12 \\
Dressing \% & 79.92 & 80.08 & 78.00 & 78.00 & 0.36 \\
& & & & & \\
Prime cut parts as percentage of carcass weight (\%) & & & & \\
Breast weight & 25.33 & 25.67 & 23.93 & 23.03 & 0.03 \\
Back weight & 11.60 & 12.73 & 11.70 & 11.70 & 0.21 \\
Drumstick weight & 9.23 & 9.30 & 9.46 & 9.50 & 0.06 \\
Neck weight & 5.90 & 5.30 & 5.70 & 5.40 & 0.03 \\
Shank weight & 7.01 & 7.51 & 6.53 & 6.41 & 0.02 \\
Thigh weight & 10.73 & 11.80 & 10.86 & 10.57 & 0.31 \\
Wing weight & 6.37 & 6.48 & 6.27 & 6.23 & 0.04 \\
& & & & & \\
Organs as percentage of live weight (\%) & 1.59 & 1.53 & 1.56 & 1.61 & 0.02 \\
Gizzard & 0.16 & 0.16 & 0.20 & 0.19 & 0.01 \\
Kidney & 2.08 & 2.10 & 2.07 & 2.12 & 0.05 \\
Liver & 1.60 & 1.68 & 1.69 & 1.70 & 0.03 \\
Abdominal fat & & & & & \\
\hline
\end{tabular}

significantly $(p>0.05)$ affected by the diets. Liver and kidney are involved in the elimination of toxins and metabolic wastes from animal's body and enlargement of these organs are always linked with the presence of antinutritional factors in the diet. This result supports the results of the phytochemical analysis of tiger nut residue in Table 2 that indicated low level of anti-nutritional substances in tiger nut residue. The non-significant effects on gizzard values indicated the absence of structural components such as wood shavings, hulls etc in the diet and also showed that the feed ingredients were welled ground. Enlargement of the gizzard is an indication of a structural component in the diet. The abdominal fats of the broilers showed no significant difference in their values. The abdominal fat value of $\mathrm{T}_{4}$ was numerically higher than $T_{1}, T_{2}$ and $T_{3}$. The abdominal fat of the broilers increases as the inclusion level of tiger nut residue in the diet increases. These results could be attributed to the high 
Table 5. Effect of tiger nut residue on haematological profile of broilers.

\begin{tabular}{lccccc}
\hline Parameters & $\mathbf{T}_{\mathbf{1}}(\mathbf{0} \%$ TNR) & $\mathbf{T}_{\mathbf{2}}(\mathbf{1 0} \%$ TNR) & $\mathbf{T}_{\mathbf{3}}(\mathbf{2 0} \%$ TNR) & $\mathbf{T}_{\mathbf{4}}(\mathbf{2 0} \%$ TNR) & $\mathbf{S E M}$ \\
\hline WBC & $7.21 \times 10^{5}$ & $7.26 \times 10^{5}$ & $7.57 \times 10^{5}$ & $7.41 \times 10^{5}$ & $0.051 \times 10^{5}$ \\
RBC $\left(10^{6} / \mathrm{W}\right)$ & $2.37 \times 10^{6}$ & $3.41 \times 10^{6}$ & $3.61 \times 10^{6}$ & $3.80 \times 10^{6}$ & $0.020 \times 10^{6}$ \\
PCV $(\%)$ & 24.33 & 29.31 & 30.14 & 31.41 & 0.032 \\
Hb (g/d) & 8.01 & 8.43 & 9.41 & 10.97 & 0.002 \\
MCV (fl) & 128.97 & 131.13 & 134.15 & 140.01 & 0.061 \\
MCH (pg) & 32.50 & 34.41 & 35.60 & 36.10 & 0.051 \\
MCHC (mg/dl) & 29.31 & 30.51 & 34.67 & 38.01 & 0.020 \\
Monocytes & 0.33 & 0.33 & 0.41 & 0.45 & 0.013 \\
Lymphocytes & 32.33 & 32.67 & 33.41 & 33.57 & 0.052 \\
\hline
\end{tabular}

Table 6. Effects of tiger nut residue on serum biochemistry of broiler chickens.

\begin{tabular}{lccccc}
\hline Parameters & $\mathbf{T}_{\mathbf{1}}$ & $\mathbf{T}_{\mathbf{2}}$ & $\mathbf{T}_{\mathbf{3}}$ & $\mathbf{T}_{\mathbf{4}}$ & $\mathbf{S E M}$ \\
\hline Total protein $(\mathrm{g} / \mathrm{dl})$ & 6.16 & 6.32 & 5.87 & 5.68 & 0.311 \\
Albumin $(\mathrm{g} / \mathrm{dl})$ & 3.17 & 3.13 & 3.37 & 3.41 & 0.130 \\
Globulin $(\mathrm{g} / \mathrm{dl})$ & 2.99 & 3.19 & 2.50 & 3.27 & 0.181 \\
Urea $(\mathrm{mg} / \mathrm{dl})$ & 2.11 & 2.71 & 3.01 & 2.41 & 0.152 \\
Creatinine $(\mathrm{mg} / \mathrm{dl})$ & 0.30 & 0.31 & 0.35 & 0.33 & 0.031 \\
Cholesterol $(\mathrm{mg} / \mathrm{dl})$ & 150.00 & 156.71 & 157.31 & 160.31 & 23.163 \\
Triglyceride $(\mathrm{mg} / \mathrm{dl})$ & 82.33 & 85.31 & 86.30 & 86.51 & 0.902 \\
Glucose $(\mathrm{mg} / \mathrm{dl})$ & 118.67 & 120.51 & 129.12 & 138.31 & 21.450 \\
\hline
\end{tabular}

ether extract in tiger nut residue. Birds are known to store excess fat in their abdomen from diet with high fat content. This result is in consonance with the report of Archibong et al. (2018) where broilers fed tiger nut based diet recorded high abdominal fat weight values. Ravindran and Savakanessan (1996) reported that fats in broiler chicken at 43 day of age accounts for as much as 10 to $15 \%$ of the total carcass weight in birds.

The result of the haematological indices of the broiler chicken is presented in Table 5. There was no significant ( $p>0.05$ ) difference in the PCV, $\mathrm{Hb}$ and RBC values across treatment. PCV, $\mathrm{Hb}$ and $\mathrm{RBC}$ have been reported to be positively correlated with the nutritional status of the animals (Adejumo, 2004). The results obtained for PCV, $\mathrm{Hb}$ and $\mathrm{RBC}$ in this study could be attributed to the high iron content in tiger nut residue as reported by Safiwa and Sampson (2013) that iron function in heme synthesis which forms haemoglobin, a protein found in red blood cells which helps in the transportation of oxygen from the lungs to body tissues to maintain basic life functions. Low PCV and haemoglobin levels are usually due to iron deficiency as reported by Arora (2010).

The insignificant variations observed in $\mathrm{RBC}, \mathrm{Hb}$ and PCV values across treatment showed that the level of tiger nut residue in the diet was able to promote normal erythropoiesis and transportation of oxygen, chemicals and nutrients essential to life. All the values obtained in this study with respect to the three haematological parameters fall within the normal range recommended for poultry by Mitruka and Rawnsley (1977).

The white blood cells counts (WBC), lymphocytes and neutrophils were not significantly affected by the diets $(p>0.05)$. The normal values obtained for the three parameters across treatments indicated that the birds were healthy throughout the experimental period being an indication of non-allergic condition, free of parasitism and foreign bodies. The values obtained for RBC, lymphocytes and neutrophils fall within the normal range recommended for poultry by Mitruka and Rawnsley (1977). MCH, MCV and $\mathrm{MCHC}$ of the broilers showed no significant differences $(p>0.05)$ in their values. $\mathrm{MCH}$ is the average mass of haemoglobin per RBC in a sample of blood. When $\mathrm{MCH}$ is low, it indicates iron deficiency, anemia. MCHC measures the average amount of haemoglobin present in a single red blood cell. MCV is a measure of the average volume of a red blood corpuscle. However, the values obtained in this study with respect to all the haematological parameters determined fall within the recommended values for poultry by Mitruka and Rawnsley (1977).

The results of the biochemical indices of the experimental broilers are shown in Table 6 . All the serum biochemical parameters determined in this study were not significantly $(p>0.05)$ affected by the diets. Serum protein did not indicate significant differences across treatment ( $p>0.05)$. The result obtained in this study showed that test ingredients in the diets did not interfere with protein metabolism. Serum protein and albumin have been reported to be directly responsive to protein intake and 
quality (Eggum 1970). TNR boosted the level of cholesterol and triglyceride of the experimental birds. Birds in $T_{4}$ recorded the highest value followed by $T_{3}, T_{2}$ and $T_{1}$.

The enzymes AST and ALT were not significantly $(p>0.05)$ influenced by the diets. AST and ALT values obtained in this study indicated normal liver function. ALT plays an active role in the biotransformation and detoxification of various toxicants. Elevated liver enzyme activities (AST and ALT) indicate liver damage.

Creatinine and urea were not significantly $(p>0.05)$ affected by the treatment diets. The non-significant differences in biochemical parameters across the dietary treatment in this study showed that the diets were adequate in nutrients and the birds were not afflicted by any serious form of toxicity. All the values obtained in the biochemical indices from this study fall within the recommended values for poultry (Mitruka and Rawnsley 1997).

\section{Conclusion}

The study showed that tiger nut residue can be used as an alternative energy source in broilers diets up to a $30 \%$ level of inclusion without any detrimental effects on the performance, carcass/organs, and blood profile of the birds. Further research should be carried out with a higher inclusion level of tiger nut residue.

\section{CONFLICT OF INTEREST}

The author declares no conflict of interest.

\section{REFERENCES}

Adejumo, D. O. (2004). Haematology, growth and performance of broiler finisher fed ration supplemented with Indian Almond. Journal of Agricultural Research, 1(1), 1-6.

Akinmutimi, A. H. (2004). Evaluation of sword bean (canavahagladiat) as alternative feed resources for broiler chickens. Thesis department of non-ruminant animal production. Michael Okpara University, Umudike, Nigeria.

Annongu, A. A., \& Olawuyi, E. I. O. (2005). Performance, blood chemistry and certain biochemical properties in pullet fed chemically treated terminalia catappa fruit waste. Journal of Raw materials Research, 2, 61-68.

AOAC (1995). Official method of Analysis 15th Edition Association official analytical chemists. Washington D.C. Pp. 68-69.

Archibong, E. E., Nsa, E. E., \& Umoren, U. E. (2018). Nutritional evaluation of tigernut (Cyperus esculentus) meal as a replacement for maize in broiler diets. Nigerian Journal of Animal Production, 45(4), 90-98.

Aregheore, E. M. (1998). A note on the nutritive value of dry ripe plantain peels as a replacement of maize for goats. Journal of Animal and feed science, 7, 55-62.

Arora, K. L. (2010). Differences in hemoglobin and packed cell volume in blood collected from different sites in Japanese Quail
(Coturnix japonica). International Journal of Poultry Science, 9(9), 828-830.

Arslam, M., Ozcan, E. M., Matir, E., Cotelioghi, U., \& Ergui, E. (2001). The effects of vitamin $E$ on some blood parameters in broilers. Turkish Journal of Veterinary and Animal Sciences, 25(5), 711-716.

Dacie, J. V., \& Lewis, S. M. (1991). Practical haematology. Churchill Livingstone. Edinburgh, 70th Edition. Pp. 521-534.

Douglas, J. H., Sullivan, T. W., Abdul-Kadir, R., \& Rupnow, J. H. (1991). Influence of infrared (micronization) treatment on the nutritional value of corn and low-and high-tannin sorghum. Poultry Science, 70(7), 1534-1539.

Eggum, B. O. (1970). Blood urea measurement as a technique for assessing protein quality. British Journal of Nutrition, 24(4), 983-988.

Elkin, R. G., Rogler, J. C., \& Sullivan, T. W. (1991). Differential response of ducks and chicks to dietary sorghum tannins. Journal of the Science of Food and Agriculture, 57(4), 543-553.

Fanimo, A. O., Oduguwa, O. O., Jimoh, Y. O., \& Faronbi, A. O. (1998). Performance and carcass evaluation of broiler chicks fed shrimp waste meal supplemented with synthetic amino acids. Nigerian Journal of Animal Production, 25(1), 17-21.

Folarunsho, O. R., \& Onibi, G. E. (2005). Assessment of the nutritional quality of Eviscerated waste from selected chicken types. In: proceedings of the 1st annual conference on Developments in Agriculture and Agricultural Technology. Federal University of Technology, Akure, Nigeria. p. 300.

lyayi, E. A. (2008). Prospects and challenges of nonconventional poultry feed stuffs. Nigerian Poultry Science Journal, 5(4), 186-194.

Mitruka, B. M., \& Rawnsley, H. M. (1977). Clinical, biochemical and hematological reference value in normal experimental animal. Mason publishing value company, New York. Pp. 3550.

National Research Council (1994). National Requirement of Poultry 9th Revised Edition. National Research Council, National Academy of Science, Washington, DC. p. 176.

Nsa, E. E. (2007) Effects of Agro Industrial by-products on the abdominal fat deposit of broiler birds. Nigerian Journal of Animal production, 18, 21-25.

Ochetim, S. (1993). The feeding and economic value of maize cob meal for broiler chickens. Asian-Australasian Journal of Animal Sciences, 6(3), 367-371.

Ojewola, G. S., Udokainyang, A. D., \& Obasi, V. (2002, March). Growth, carcass and economic response of local turkey poults to various levels of dietary energy. In: Increasing household protein consumption through livestock products. Proceedings of the 27th Annual Conference of Nigeria Society for Animal Production, Akure, Nigeria (pp. 167-169).

Okike, I., Samireddypalle, A., Kaptoge, L., Fauquet, C., Atehnkeng, J., Bandyopadhyay, R., Kulakow, P., Duncan, A. J., Alabi, T., \& Blummel, M. (2015). Technical innovations for small-scale producers and households to process wet cassava peels into high quality animal feed ingredients and aflasafe ${ }^{\mathrm{TM}}$ substrate. Food Chain, 5(1-2), 71-90

Olafehehan, C. O., Obun, A. M., Yusuf, M. K. Adewumi, O. O., Oladefehehan, A. O., Awofolaji, A. O., \& Adenij, A. A. (2010). Effects of residual cyanide in processed cassava peel meals on haematological and biochemical indices of growing rabbits. Proceedings of 35th Annual Conference of Nigerian Society for Animal Production, p. 212.

Ravindran, P. S., \& Savakanessan, N. O. (1996). The influence of growth performance, carcass characteristics and economics 
of production of starter broiler chickens. Journal of Animal Veterinary Advances, 6(11), 1323-1327.

Samson, B. W., \& Safiya, S. (2013). Assessment of the Nutritional and Anti-nutritional components of tiger nut residue. International Journal of Science and Research, 4(6), 342-345.

SPSS (2004). Statistical Package for Social Sciences, Procedure and Facilities for Research. MCGraw-Hill Book Company, New York.

Van Krimpen, M. M. Kwakkel, R. P, Andre, G., Denttartog, L. A., \& Verstegen, M. W. A. (2006). Effects of nutrition dilution and feed intake, eating and performance of broilers. British Poultry Science, 48(4),389-398.
Vetstreet (2011). Serum biochemistry profile. Retrieved from http://www.vetstreet.com/care/serum-biochemistry-profile.

WHO (1980). Manual of Basic Techniques for a Health Laboratory. World Health Organization, Geneva, Pp. 360-406. Wikipedia (2016). The free Encyclopedia. Retrieved from https://en.wikipedia.org/wiki/Akwa_lbom_State. 